a juniper bush and a mallow.

A few thin voles. Australian

ostrich, one. One Vertol helicopter

and a river-boat, punted,

from former French Dahomey.

He with his hand still quiescent

on her belly, she all the while

with her hand on his knee.

Corned Beef from Argentina,

Vodka-Wyborowa. Attaché,

pride of peasants from rice village,

spectacular supernumeraries,

soaked in oil, from a Persian

film. Some mothers. One Bolivian.

Cannabis and lingonberry, rape, ricin.

Round about, in darkness,

Aland's Baltic cliffs.

Translated by the author with Elliott Anderson

SUTARDJI CALZOUM BACHRI / INDONESIA

\title{
A Package of Love to an Indonesian Lady in Jakarta from an Indonesian Gentleman in Iowa City USA
}

some people send a package of flowers for love

some people send a package of blood for love

some people send a package of tears for love

and I send my penis to my love

so let my penis grow longer and longer

so it can reach thirteen thousands miles

between you and me without any help from the postal system

since the United States Mail doesn't carry any packages more than three and

half feet in length 
well my lady my dear my love don't cry take it easy

open your soul and mind and be naked

and let us hope that my almighty penis

can stand erect long and long and great

like the flagpole of United Nations in New York City

soaring and reaching peace to you

amen

Translated by the author and Harry Aveling

REZA BARAHENI / IRAN

\section{Cemetery}

The criminal prison autumn

has arrived outside without

us seeing its signs

If we were

in Darakeh now

we could see

the cemetery of yellow leaves

And now that we are not there

we had better put

our heads on the cold tiles of the cell

and sleep until

the sound of shooting startles us

and we rush

to the hole in the cell's iron door

and if the windowlet is open

watch the silent caravan of the innocent

like Ardaviraf who saw

pre-Islamic hell dwellers

like Mohammed

who saw post-Islamic hell dwellers

The identity of the caravan of the innocent

will not be proven in the course of time

Future archaeologists 